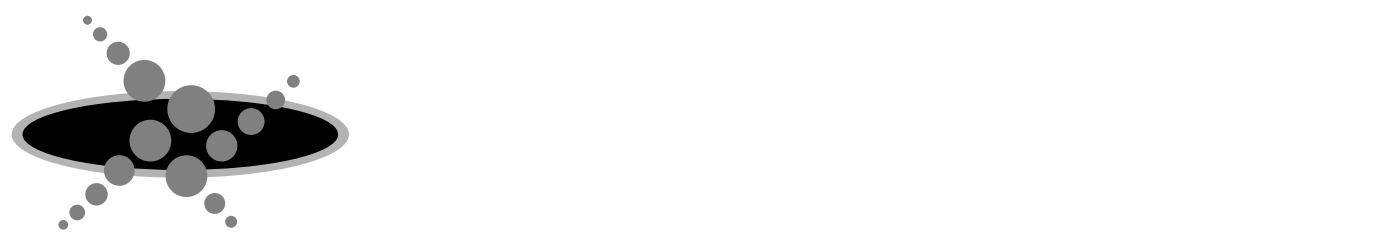

\begin{abstract}
Heme-based sensor proteins have become known to be a new member of hemeproteins in which the heme acts as the active center for sensing gas molecules such as $\mathrm{O}_{2}, \mathrm{CO}$, and NO. HemAT and CooA are the $\mathrm{O}_{2}$ and $\mathrm{CO}$ sensor proteins, respectively. HemAT is a signal transducer protein in the aerotaxis control system in Bacillus subtilis. CooA is a transcriptional activator that regulates the expression of some proteins responsible for CO metabolism in Rhodospirillum rubrum. Here, the structure and function of HemAT and CooA are reviewed.
\end{abstract}

hemeprotein / sensor protein / signal transducer / aerotaxis / transcriptional activator

\section{1.はじめに}

酸素, 窒素, 一酸化窒素, 一酸化炭素などの気体分子 が, 酵素反心の基質, あるいは反応生成物となることは よく知られている. これに対し, 近年, 気体分子がシグナ ル分子として機能し, さまざまな生理機能の制御に関 与していることが報告され, 気体分子の新規な機能と して, 注目を集めている. 代表的な例を Table 1 に示す. 気体分子が生理機能を発揮する例としては, 一酸化窒 素 (NO) が最もよく知られている. NOは, 可溶性グア ニル酸シクラーゼ ( $\mathrm{sGC}$ ) のエフェクターとして機能 し, sGCに結合することにより, 兴の酵素活性を数百倍 に高める. NO以外にシグナル分子として機能すること か報告されている気体分子としては, エチレン, 酸素, 一 酸化炭素がある. エチレンは, 植物ホルモンとして機能 し, 植物の発芽, 成長, 老化, 果実の成熟などの制御に関 与している. エチレンレセプター (センサー) タンパク

Table 1 Typical examples for gaseous molecule sensor proteins

\begin{tabular}{ccl} 
Sensor Protein & Effector & Function \\
\hline sGC & $\mathrm{NO}$ & Guanylate cyclase \\
ETR1 & $\mathrm{C}_{2} \mathrm{H}_{4}$ & Ethylene receptor \\
FixL & $\mathrm{O}_{2}$ & Sensor-kinase \\
HemAT & $\mathrm{O}_{2}$ & Signal transducer \\
DOS & $\mathrm{O}_{2}$ & Phosphodiesterase \\
AxPDEA1 & $\mathrm{O}_{2}$ & Phosphodiesterase \\
CooA & $\mathrm{CO}$ & Transcriptional activator \\
\hline
\end{tabular}

質であるETR1 にエチレンが結合することにより一連 のシグナル伝達反応か開始されると考えられているが, その詳細についてはほとんどわかっていない. 酸素が シグナル分子として機能する系としては, 根粒細菌中 に存在する 2 成分情報伝達系 (two-component system) を構成するセンサーキナーゼ, FixLがある. FixL は, 根 粒細菌中での窒素固定化酵素 (ニトロゲナーゼ) の発 現を酸素依存的に制御している. 酸素によるFixLの機 能制御機構に関しては, 以前に本誌において解説され ていることもあり1), 本稿では取り上げない.

生体系において, 気体分子がシグナル分子として機能 するためには, 気体分子のレセプター (センサー) タン パク質の存在が必要不可欠である. NOを例外 (NOは システイン側鎖のチオール基と反応し, ニトロソチオ 一ルを生成する) とすれば, ほかの気体分子は単純タン パク質と直接, 相互作用することはない.したがって, こ れらの気体分子をセンシングするためには, これら気 体分子と相互作用可能な, 何らかの補欠分子族が必要 となる. Table 1 に示したセンサータンパク質の例では, 銅イオンを含むと考えられているETR1以外はすべて, 補欠分子族としてへム (鉄ポルフィリン錯体) を有し ている.

ヘムタンパク質は, 代表的な金属タンパク質であり, 酸素の運搬 - 貯蔵, 電子伝達, 各種基質の酸化還元反応 など, 多種多樣な機能を示すことか知られている. しか しながら, 気体分子センサーとしての機能は, へムタン パク質の機能としてはこれまで知られていない, 新規

\title{
Structure and Function of Heme-Based Sensor Proteins
}

Shigetoshi AONO

Center for Integrative Bioscience, Okazaki National Research Institutes 
な機能である.したがって,気体分子のセンシング,なら びにシグナル分子である気体分子をセンシングした後 のシグナル伝達に, 分子中のへムがどのように関与し ているのかという分子機構の解明に興味がもたれてい る. ここでは, 酸素センサータンパク質HemAT, COセ ンサータンパク質CooA を取り上げ, 著者らの研究成果 を中心に, これらセンサータンパク質の性質について 述べる。

\section{2 .酸素センサータンパク質HemAT の構造と機能}

2.1 酸素に対する走化性シグナルトランスデューサー 枯草菌Bacillus subtilis 中に含まれるHemAT は, 本菌 の酸素に対する走化性 (aerotaxis) 制御系において, 酸 素センサーとして機能するシグナルトランスデューサ ータンパク質である. 走化性とは, 外部シグナル (糖, ア ミノ酸, 金属イオン, 酸素などの化学物質が代表的なも のである)に対して,細菌か誘引されるかあるいは忌避 する反応をいう.さまざまな外部シグナルに対応する ため, 細菌中には複数のシグナルトランスデューサー タンパク質が存在する. 枯草菌中には 10 種類程度のシ グナルトランスデューサータンパク質が存在すると考 えられており, HemATは兴のうちの1つである.

HemAT は, $\mathrm{N}$ 末端側に存在するセンサードメインと

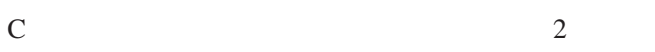
メインから構成されていると推定されている21. HemAT中のシグナリングドメインのアミノ酸配列は, これまでに報告されているほかの走化性シグナルトラ ンスデューサータンパク質のシグナリングドメインと 高い相同性を示す.一方, HemATのセンサードメイン は, 酸素貯蔵タンパク質であるミオグロビンとアミノ 酸配列の相同性を有している21. ミオグロビンでは, 分 子中に含まれるへムに酸素分子が可逆的に配位するこ とにより, 酸素貯蔵タンパク質としての機能が発現し ている. アミノ酸配列の相同性から推測されるとおり, HemATセンサードメイン中に, ミオグロビンの場合と 同樣, 酸素が可逆的に配位可能なへムが含まれている とすれば, へムか酸素センサーの活性中心として機能 している可能性が高いと考えられる.では, 実際に HemAT中にへムは含まれているのであろうか?

\section{2 ミオグロビンとよく似たHemAT センサー} ドメイン

大腸菌中で発現させた組換え型HemATを精製し, 電 子吸収スペクトルを測定すると, ミオグロビンによく 似たスペクトルが観測される. このことから, HemAT は実際にへムタンパク質であることがわかった. HemAT中に含まれるへムは, へモグロビンやミオグロ
Table 2 Kinetics and equilibrium constants for the reaction of ferrous HemAT-Bs ( Bacillus subtilis) with oxygen compared to those of other hemeproteins

\begin{tabular}{lccc} 
Hemeproteins & $k_{\text {on }} / \mu \mathrm{M}^{-1} \mathrm{~s}^{-1}$ & $k_{\text {off }} / \mathrm{s}^{-1}$ & $K_{\mathrm{d}} / \mathrm{nM}^{\mathrm{b}}$ \\
\hline HemAT-Bs & 32 & 23 & 719 \\
Sw Mb & 17 & 15 & 882 \\
Hb A $\alpha$-chain & 23 & 11 & 478 \\
$\begin{array}{l}\text { (R-state) } \\
\text { Hb A } \beta \text {-chain }\end{array}$ & 79 & 28 & 354 \\
(R-state) & & & \\
M $t$ Hb & 25 & 0.199 & 7.96 \\
Bj FixL & 0.14 & 20 & $140 \times 10^{3}$
\end{tabular}

${ }^{a}$ Abbreviations: $S w \mathrm{Mb}$, sperm whale myoglobin; $\mathrm{Hb}$, hemoglobin; Mt $\mathrm{Hb}$, Mycobacterium tuberculosis hemoglobin; Bj FixL, Bradyrhizobium japonicum FixL.

${ }^{\mathrm{b}} K_{\mathrm{d}}$ is given by the ratio $k_{\text {off }} / k_{\text {on }}$.

ビンの場合と同樣にb型へムであることもわかった ${ }^{3)}$. 精製したHemATは, 产の分子中に酸素分子か配位した 酸素化 (オキシ) 型として存在している. HemAT中の へムへの酸素の配位は, ミオグロビンの場合と同樣に 可逆的である. オキシ型HemAT とジチオナイトナトリ ウムを反応させると, 脱酸素化反応が進行し, 5 配位高 スピン型へムを含む; デオキシ型HemATが生成する. デオキシ型HemAT と酸素を反応させると, オキシ型 HemATが, 再び生成する. また, デオキシ型HemAT と $\mathrm{CO}$ を反応させると,へムにCOか配位した $\mathrm{CO}$ 結合型 HemATか甡成する. このように, HemAT中のへムに可 逆的に酸素か配位可能であるという事実は, 上述した ようにHemAT中のへムか酸素センサー本体として機 能していることを強く示唆している.

HemATによる酸素センシング機構を明らかにする ため, HemAT と酸素との反応, 分子中のへムに酸素が 結合したオキシ型HemATの構造などについて検討し $た^{3}$. HemAT と酸素との反応における酸素の結合 $\left(k_{\text {on }}\right)$ および解離速度定数 $\left(k_{\mathrm{off}}\right)$ を, ほかの酸素結合へムタ ンパク質と比較した結果を Table 2 に示す. HemATは, ミオグロビンの場合とほぼ同樣な $k_{\mathrm{on}}$ および $k_{\mathrm{off}}$ の值を 示すことがわかった. $k_{\mathrm{on}}$ および $k_{\mathrm{off}}$ の值から推定した HemAT の酸素に対する親和性 $\left(K_{\mathrm{d}}=719 \mathrm{nM}\right)$ は, 呼 吸鎖の末端酸化酵素の酸素に対する $K_{\mathrm{m}}$ 值とほほ同樣な 值である. このことは, HemAT の生理的な役割を反映 しているものと考えられる. 枯草菌中に含まれる HemATは, 本細菌の酸素に対する正の走化性発現のた めの酸素センサーとして機能していると考えられてい る. すなわち, HemATは, 枯草菌力酸素呼吸て甡育する ために最適な酸素濃度をセンシングしていることにな る. 呼吸鎖の末端酸化酵素の酸素に対する $K_{\mathrm{m}}$ 値と 
HemATの酸素に対する $K_{\mathrm{d}}$ 值がほぼ同樣の值を示すこ とは, 酸素呼吸で生育するために最適な酸素濃度をセ ンシングするためには好都合であると考えられる.

2.3 HemAT中に含まれるへムの分光学的特徵 ${ }^{3)}$

デオキシ型HemATの共鳴ラマンスペクトルは, ヒス チジン (His) をへム軸配位とする 5 配位高スピン型へ ムに特徵的なものであった. また, CO結合型HemAT で は, $v(\mathrm{Fe}-\mathrm{CO})$ および $v(\mathrm{C}-\mathrm{O})$ が炎れ攵れ494および $1964 \mathrm{~cm}^{-1}$ に観測された. これらの值は, COのトランス 位に存在するへム軸配位子が電気的に中性なHisであ ることを示唆している. HemAT とミオグロビンのアミ ノ酸配列を比較すると, HemAT の場合もミオグロビン の軸配位子 (近位ヒスチジン) に相当する位置にHis ${ }^{123}$ が保存されている. His ${ }^{123}$ をグリシンに置換した変異体 (H123G HemAT) は, へムを含まないアポタンパク質 として発現する. これらの結果を総合すると, HemAT 中に含まれるへムは His ${ }^{123}$ を近位側へム軸配位子とし ていると考えられる.

オキシ型HemATの共鳴ラマンスペクトルでは, 560 $\mathrm{cm}^{-1}$ に $\mathrm{Fe}-\mathrm{O}_{2}$ に基づくラマンバンド $v\left(\mathrm{Fe}-\mathrm{O}_{2}\right)$ カ観測され る. 通常のへモグロビン, ミオグロビンの場合, $v\left(\mathrm{Fe}-\mathrm{O}_{2}\right)$ は $570 \mathrm{~cm}^{-1}$ 付近に観測される.一方, 結核菌 Mycobacterium tuberculosis 由来のへモグロビン $(M t \mathrm{Hb})$ では, HemAT の場合と同樣, $v\left(\mathrm{Fe}-\mathrm{O}_{2}\right)$ は560 $\mathrm{cm}^{-1}$ に観測される. $M t$ $\mathrm{Hb}$ において通常のへモグロビン, ミオグロビンよりも 低波数側にv(Fe- $\left.\mathrm{O}_{2}\right)$ か観測されるのは, へムに配位し た酸素分子とへムポケットのアミノ酸残基間で形成さ れる水素結合の樣式が異なっているためであると推定 されている. すなわち, 通常のへモグロビン, ミオグロビ ンの場合, 遠位ヒスチジンとよばれるヒスチジン残基 と, へムに配位した酸素分子のうち, へム鉄に直接配位

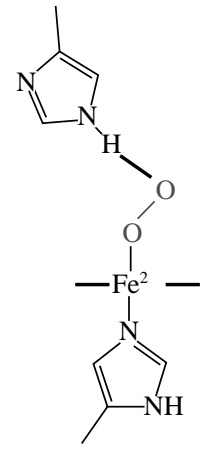

a) $\mathrm{Sw} \mathrm{Mb}, \mathrm{Hb} \mathrm{A}$

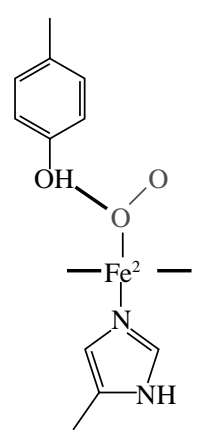

b) $M t \mathrm{Hb}$

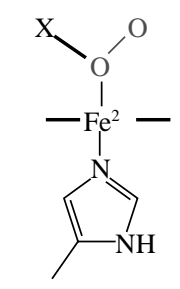

c) HemAT
Fig.1 Coordination structure of the heme in ( a) Sperm whale ( $\mathrm{Sw}$ ) $\mathrm{Mb}$ and $\mathrm{Hb} \mathrm{A},(\mathrm{b})$ Mycobacterium tuberculosis ( $M t) \mathrm{Hb}$, and ( c) HemAT.
していない酸素原子との間で水素結合が形成されてい る (Fig.1a). これに対し, $M t \mathrm{Hb}$ においては, チロシン 残基とへム鉄に直接配位した酸素原子との間で水素結 合が形成されていると考えられている (Fig.1b). 現時 点では, 配位酸素分子と水素結合を形成するアミノ酸 残基の同定はなされていないが, HemATの場合も $M t$ $\mathrm{Hb}$ と同樣, 配位酸素分子のうち, へム鉄に直接配位した 酸素原子と遠位側アミノ酸残基との間で水素結合が形 成されているのではないかと考えられる (Fig.1c). こ のような特異な水素結合樣式が, HemATの機能 (酸素 センシング, シグナル伝達) 発現に深くかかわっている のではないかと推定されるが, 弚の実態についてはま ったく不明な状況である. この点も含め, HemATに関 してはまだ研究が始まったばかりであり, 詳細な構造 と機能の解明は今後の課題として残されている.

3.CO センサータンパク質CooA の構造と機能4)-15)

\subsection{CO に依存した遺伝子発現制御}

CooA は, 紅色非硫黄光合成細菌 Rhodosprillum rubrum 中に含まれる転写調節因子である. 本菌は, 嫌気 条件下においてCOが存在すれば, CO を唯一のエネル ギー源として生育することが可能である. この場合,

(1) 式および (2) 式の反応を共役させて進行させるこ とにより, 生育のためのエネルギーを獲得している ((3) 式).

$$
\begin{aligned}
& \mathrm{CO}+\mathrm{H}_{2} \rightarrow \mathrm{CO}_{2}+2 \mathrm{H}^{+}+2 \mathrm{e}^{-} \\
& 2 \mathrm{H}^{+}+2 \mathrm{e}^{-} \rightarrow \mathrm{H}_{2} \\
& \mathrm{CO}+\mathrm{H}_{2} \rightarrow \mathrm{CO}_{2}+\mathrm{H}_{2} \quad \Delta G^{0}=-20 \mathrm{~kJ} \mathrm{~mol}^{-1}
\end{aligned}
$$

(1) 式および (2) 式の反応を触媒する $2 つ$ 酵素, 一酸化 炭素脱水素酵素およびヒドロゲナーゼの発現は, 転写レ ベルにおいて制御されている. これらCO代謝にかかわ る一連のタンパク質は, 嫌気条件下において COが存在 する場合にのみ発現する.CooAがCOセンサ一機能を有 する転写活性化因子として機能することにより, COに 依存したこれらタンパク質の発現制御がなされている. $3.2 \mathrm{CooA}$ 中に含まれるへムが示す特異な性質 CooA は, 221 アミノ酸からなるサブユニットが2個 会合した, $\alpha 2$ 型ホモダイマー構造を有している. 各サブ ユニットには 1 分子のb 型へム (プロトへム) が含ま れており, このへムがCOセンサーの本体として機能し ている. CooA中に含まれるへムは, 従来のへムタンパ ク質ではみられない特異な配位構造をもつことが明ら かになっている. 配位構造を Fig.2 に示すとともに, 光 の代表的な特徵を下記に述べる.

(1) アミノ末端 (N末端) 残基である $\mathrm{Pro}^{2}$ が, 酸化型お よび還元型へムの軸配位子として機能している.こ 


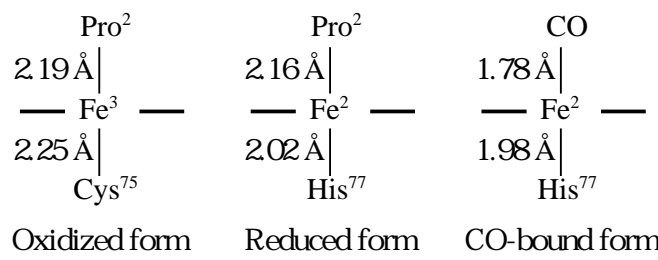

Fig.2 Coordination structure of the heme in CooA. The bond length between iron and the axial ligand atoms shown in the figure are estimated by EXAFS analyses.

のとき,一方のサブユニットの $\mathrm{N}$ 末端Proが別のサ ブユニット中のへムに配位していることが, 還元型 CooAのX線結晶構造解析から明らかにされてい る ${ }^{15)}$. CooA は, Proが金属タンパク質中の金属イ才 ンに配位可能であることを示した初めての（また， 現時点では唯一の) 例である.

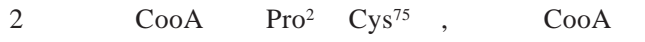
は $\mathrm{Pro}^{2}$ と $\mathrm{His}^{77}$ がへム軸配位子として機能してい る. このことは, へム鉄の酸化状態変化に伴い, $\mathrm{Cys}^{75}$ と $\mathrm{His}^{77}$ との間て軸配位子交換反応が進行すること を示している.

(3) 還元型CooA は, 配位飽和な6配位型へムを有して いるにもかかわらず, 生理的条件下において容易に $\mathrm{CO}$ と反応し,へムに COが配位した $\mathrm{CO}$ 結合型 CooA を生成する.

酸化型 $\mathrm{CooA}$ の電子スピン共鳴 (ESR) スペクトル の $g$ 值および線形は, システイン由来のチオレートア ニオンか軸配位したシトクロムP450のESR スペクト ルと非常に類似している. また, 後述するように, CooA の酸化還元電位は非常に低い負の電位を示す.これら のことから, 酸化型CooA 中のへムに軸配位している $\mathrm{Cys}^{75}$ は, シトクロムP450の場合と同樣にチオレート アニオンの形でへムに配位していることが示される.

モノオキシゲナーゼとして機能するシトクロムP 450 の場合, へムに軸配位したチオレートアニオンの強い 電子供与性がへム鉄上での酸素の活性化に寄与してい ると考えられている. 一方, CooAの場合には, エフェク ター分子であるCOがへム上で化学反応するわけでは なく,へムに可逆的に結合するにすぎない. したがって， チオレートアニオンがムムに軸配位していることの意 味は, シトクロムP450の場合とはまったく異なるであ ろう. 兴れでは, CooA中のへムにチオレートアニオン か漸配位していることの生理的な意義は何なのであろ うか? 現時点では残念ながら, 弚の答えはよくわか

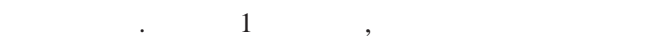
通じてCooAの活性化，不活性化の制御にかかわってい
るという可能性が考えられる. 後述するように, CooA はCOか結合したCO結合型のみか転写活性化因子とし ての活性を有している. このことは, R. ruburum 中に含 まれ, CooAにより発現制御されているCO代謝に関与 するタンパク質の発現が,「嫌気条件下でCOが存在す る場合のみ」誘導されるという事実とよく対応してい る. すなわち, CooA か転写活性化因子としての活性を 獲得するためには, 分子中のへムに $\mathrm{CO}$ 力配位する必要 がある. 谷のためには, COか存在するだけではなく、へ ムは還元型, すなわちへム鉄イオンが還元された2価の 状態である必要がある.R. ruburumか好気条件下におか れた場合には, CooA 中のへムは酸化され,たとえCOが 存在してもCooA は不活性な状態となる. CooAを活性 化し, $\mathrm{CO}$ 代謝に関与する酵素系を発現する際には, 細 胞内が十分な還元状態 (嫌気状態)に保たれている必 要がある. CooA中のへムはCOセンサーとして機能し ているのみならず, 細胞内のレドックスセンサーとし ての機能も併せもっており,へムの酸化還元を通じて 細胞内の好気/嫌気状態をセンシングしていると考え ることができる. CooA中のへムにチオレートアニオン か軸配位している生理的意義は, $\mathrm{CO}$ 代謝に関与する酵 素系を発現するために必要十分な嫌気状態においての みへムの還元が進行するよう, へムの酸化還元電位を 調節しているのではないかと考えられる.

\section{3 八厶の酸化状態変化に伴う軸配位子交換反応}

へ 鉄の酸化状態变化に伴う, $\mathrm{Cys}^{75}$ と $\mathrm{His}^{77}$ との間で 軸配位子交換反応を, パルスラジオリシス法により解 析した結果をFig.3に示す. パルスラジオリシス法では, 酸化型CooAの溶液に電子線パルスを照射し, 水和電子 により CooAを一過的に還元した後, 時間分解過渡吸収 スペクトルを測定することにより反応を追跡する. 光 の結果, 酸化型CooAから還元型CooAへの反応は, $2 つ$ の反応中間体を経て進行することが明らかとなった． 第1の中間体 (中間体 1 ) は, $450 \mathrm{~nm}$ 付近にSoret帯の 吸収ピークを示し, 時定数 $40 \mu \mathrm{s} の 1$ 次反応で第 2 の中 間体 (中間体 2 ) へと変化する. 中間体 2 が生成する過 程においては, $450 \mathrm{~nm}$ 付近の吸収ピーク強度が咸少し, かわりに $420 \mathrm{~nm}$ 付近の吸収強度か増加する. 中間体 2 は, 時定数 $2.9 \mathrm{~ms}$ の 1 次反応て最終生成物である還元型 CooAへと変化する.

$\mathrm{His}^{77}$ を Gly に置換した变異体, H77G CooA 用いて 同樣な測定を行った. 本变異体では, 還元型へムの軸配 位子である $\mathrm{His}^{77}$ がないため, 野生型て観測される $\mathrm{Cys}^{75}$ と $\mathrm{His}^{77}$ との間での軸配位子交換反応は進行しない. に もかかわらず, H77G CooAにおいても, 野生型と同樣, 2つの反応中間体を経て, 酸化型から還元型への変化が 


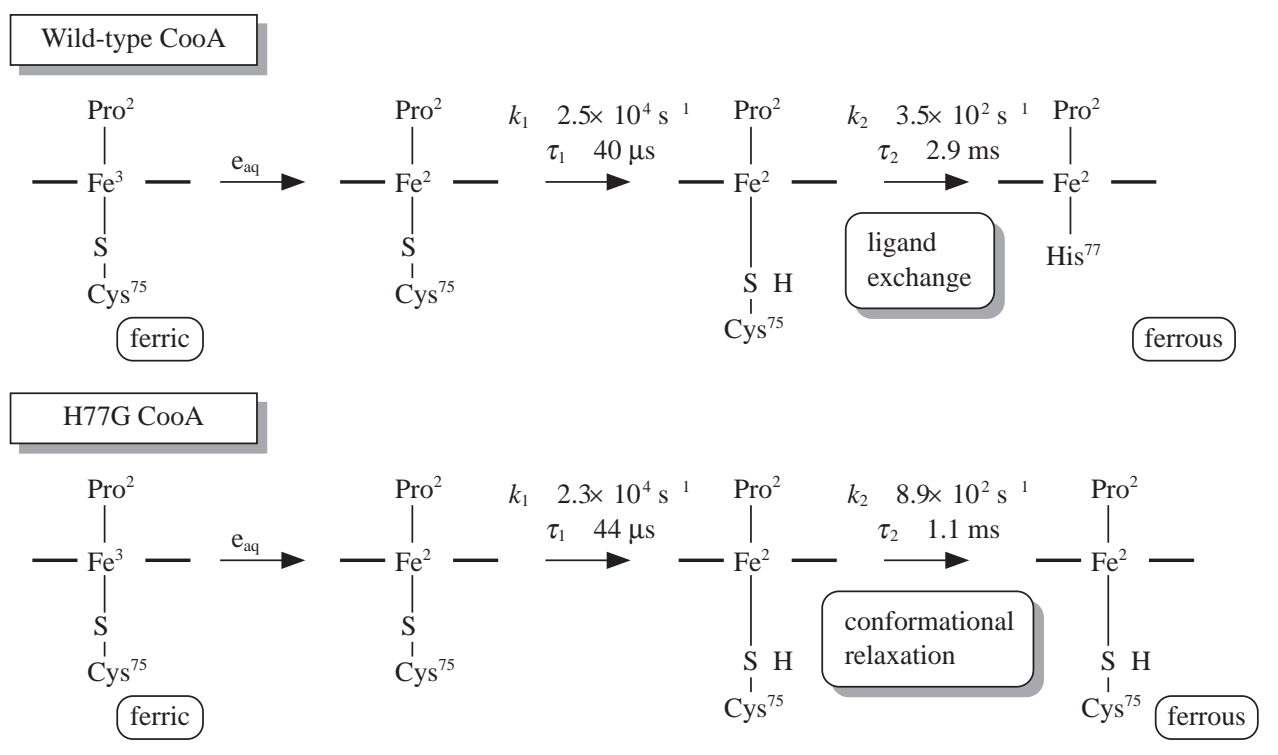

Fig.3 Scheme for ligand exchange reaction in wild-type and H77G CooA.

進行することがわかった. また, 時定数は一部異なるも のの, 観測される過渡吸収変化は, 基本的には野生型の 場合と同樣であつた.

上記の結果を総合すると,酸化型から還元型へと変化 する際の軸配位子交換反応機構として, 以下のような モデルが考えられる. まず,へム鉄が還元され,酸化型へ ムに配位していた軸配位子 $\left(\mathrm{Pro}^{2}\right.$ と $\mathrm{Cys}^{75}$ チオレートア ニオン) が爫のまま軸配位子となっている中間体 1 が 生成する. ついで, $\mathrm{Cys}^{75}$ チオレートアニオンがプロトン 化した, あるいは鉄 - 硫黄間の結合距離が伸びた中間 体 2 が生成する. 中間体 2 では, $\mathrm{Cys}^{75}$ と $\mathrm{His}^{77}$ が存在する 側のポリペプチド鎖の構造緩和を伴いながら, $\mathrm{Cys}^{75}$ か ら $\mathrm{His}^{77}$ への軸配位子交換反応が進行しているものと考 えられる.H77G CooA では, 野生型と同樣, Cys ${ }^{75}$ が存在 する側のポリペプチド鎖の構造緩和が起こっており, この過程が中間体 2 から最終生成物への変換過程 (時 定数 $1.1 \mathrm{~ms})$ に対応しているものと推定される.

$3.4 \mathrm{CO}$ によるCooA の活性化

CooAの活性はCOにより制御されている. すなわち, 分子中のへムに $\mathrm{CO}$ か配位した $\mathrm{CO}$ 結合型 $\mathrm{CoOA}$ の が, 転写活性化因子としての活性を有しており, 酸化型 および還元型CooA は転写活性化因子としての活性を 示さない. CooAの転写活性化因子としての活性は, 特 異的DNA結合能の有無により制御されている. CO結 合型CooAのみか標的DNA に対する特異的結合能を有 している. 一方, 酸化型および還元型 CooA は, 標的 DNA に対する特異的結合能を有していないため, 転写
活性化因子としての活性も示さない.

CooA は, へムを含むセンサードメインと, DNA結合 モチーフであるへリックス・ターン・ヘリックスを含 むDNA結合ドメインの 2 つのドメインから構成されて いる. 各サブユニット中のへリックス・ターン・ヘリ ックスモチーフは, 2 回対称性を有するCooAの標的 DNA 中の塩基配列 (5'- tGTC (a/g) …*. (c/t)GAC-3', ·はCooA結合には関与しない塩基を示す) を認識し, 特異的に結合する. 塩基配列に変異を導入した变異型 プロモーターを用いた実験から, 上記の塩基配列のう ち, 大文字で示した部分の塩基対がCooA による特異的 認識および特異的結合に関与していることか明らかと なっている. CooAが不活性な (標的DNA に対する特 異的DNA結合能を示さない) 状態では, CooA ダイマ 一中でのへリックス・ターン・ヘリックスモチーフの 配置が, 2 回対称性を有するCooA結合配列と相互作用 できないような状態にあると考えられる. CooA 件異 的DNA結合能を獲得するのは, CooA中のへムにCOが 結合することでなんらかの構造変化か誘起され, 弚の 結果, ヘリックス・ターン・ヘリックスモチーフの配 置がCooA 結合配列にフィットするよう変化するため であると考えられる.

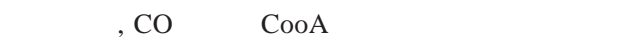
うになっているのであろうか. 上述したように, CooA 中の還元型へムは, 配位飽和な状態にあるにもかかわ らず容易にCO と反応し, $\mathrm{CO}$ 結合型へムを生成する. COがCooA 中のへムに配位する際には, 還元型へムに 
配位していた, $\mathrm{N}$ 末端アミノ酸残基である $\mathrm{Pro}^{2}$ がムか ら解離する. したがって, $\mathrm{N}$ 末端領域のポリペプチド鎖 は, へムにCOか配位することにより, 弚のコンホメー ションが大きく変化するものと予想される. 単純に考 えると, このコンホメーション変化がCooAの構造変化 を誘起することにより, CooAの活性化が進行している のではないかと推察される. この予想が正しいかどう か確かめるため, $\mathrm{N}$ 末端領域のアミノ酸を削除した変異 型CooAを調製し, 㒷の性質を調べてみた. 产の結果, $\mathrm{N}$ 末端から 4 残基あるいは 14 残基のアミノ酸を切除した 変異体も, 野生型の場合と同樣, $\mathrm{CO}$ 存在下でのみ転写 活性化因子としての活性を示した.さらに興味深いこ とに, これらの変異体では, 本来の軸配位子である $\mathrm{Pro}^{2}$ が欠損しているにもかかわらず, 変異体中の還元型へ ムは6配位構造を取っている. このことは, 本来の軸配 位子である $\mathrm{Pro}^{2}$ が欠損していても, 谷のかわりになん らかのアミノ酸残基がムに軸配位していることを示 している. 現在, $\mathrm{Pro}^{2}$ のかわりに何がへムに軸配位して いるかは確定していないが, $\mathrm{N}$ 末端のアミノ基がムム 軸配位している可能性か高いと考えている.

これらのことを考えあわせると, COによるCooA 活 性化においては, $\mathrm{Pro}^{2}$ がへムから解離することによる, $\mathrm{N}$ 末端領域のポリペプチド鎖のコンホメーション変化 が本質的に重要なわけではないのかもしれない. 光れ よりも, $\mathrm{Pro}^{2}$ がムから解離することにより, へムと $\mathrm{His}^{77}$ を含む近位側アミノ酸残基のコンホメーション変 化が誘起されることでCooA 分子の構造変化が進行し ている可能性が考えられる. ただし, 現時点ではこのよ うな仮説を裏づける実験結果はなく, 今後の検討課題 として残されている.

\section{4.おわりに}

本稿では,「気体分子のセンサーとして機能するへム タンパク質」のなかでも, 著者らが研究対象としてい るものを中心に取り上げた. 現在, これら以外にも, 続々と新しいへム含有センサータンパク質が報告され

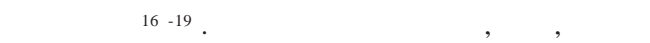
機化学および生物物理化学の研究分野における中心的 研究課題として取り上げられることを期待している.

\section{謝 辞}

ここて紹介した研究は,多くの共同研究者との協力で 行われたものです.下記の参考文献中, 著者と連名とな つている共同研究者の方々に感謝致します. また, 本研 究の一部は, 科学研究費 (特定領域研究B「金属関与
するセンサーとスイッチのケミカルバイオロジー」(課 題番号 12147203), 基盤研究B (課題番号 14655304)) による支援を受けました。

\section{文 献}

1) 中村寛夫, 城宜嗣 (2001) 生物物理 41, 295-298.

2) Hou, S., Larsen, R. W., Boudko, D., Riley, C. W., Karatan, E., Zimmer, M., Ordal, G. W. and Alam, M. (2000) Nature 403, 540-544.

$3)$ Aono, S., Kato, T., Matsuki, M., Nakajima, H., Ohta, T., Uchida, T. and Kitagawa, T. (2002) J. Biol. Chem. 277, 13528-13538.

4) Aono, S., Nakajima, H., Saito, K. and Okada, M. (1996) Biochem. Biophys. Res. Commun. 228, 752-756.

$5)$ Aono, S., Matsuo, T., Shimono, T., Ohkubo, K., Takasaki, H. and Nakajima, H. (1997) Biochem. Biophys. Res. Commun. 240, 783-786.

6) Uchida, T., Ishikawa, H., Takahashi, S., Ishimori, K., Morishima, I., Ohkubo, K., Nakajima, H. and Aono, S. (1998) J. Biol. Chem. 273, 19988-19992.

7) Aono, S., Ohkubo, K., Matsuo, T. and Nakajima, H. (1998) J. Biol. Chem. 273, 25757-25764.

8) Aono, S., Takasaki, H., Unno, H., Kamiya, T. and Nakajima, H. (1999) Biochem. Biophys. Res. Commun. 261, 270-275.

9) Uchida, T., Ishikawa, H., Ishimori, K., Morishima, I., Nakajima, H., Aono, S., Mizutani, Y. and Kitagawa, T. (2000) Biochemistry 39, 12747-12752.

10) Kumazaki, S., Nakajima, H., Sakaguchi, T., Nakagawa, E., Shinohara, H., Yoshihara, K. and Aono, S. (2000) J. Biol. Chem. 275, 38378-38383.

11) Nakajima, H., Nakagawa, E., Kobayashi, K., Tagawa, S. and Aono, S. (2001) J. Biol. Chem. 276, 37895-37899.

12) Yamamoto, K., Ishikawa, H., Takahashi, S., Ishimori, K., Morishima, I., Nakajima, H. and Aono, S. (2001) J. Biol. Chem. 276, 11473-11476.

13) Nakajima, H., Honma, Y., Tawara, T., Kato, T., Park, S. -Y., Miyatake, H., Shiro, Y. and Aono, S. (2001) J. Biol. Chem. 276, 7055-7061.

14) Rubtsov, I. V., Zhang, T., Nakajima, H., Aono, S., Rubtsov, G. I., Kumazaki, S. and Yoshihara, K. (2001) J. Am. Chem. Soc. 123, 10056-10062.

15) Lanzilotta, W., Roberts, G., Poulos, T. L. et al. (2000) Nat. Struc. Biol. 7, 876-880.

16) Hou, S., Freitas, T., Alam, M. et al. (2001) Proc. Natl. Acad. Sci. USA 98, 9353-9358.

17) Tomita, T., Ikeda-Saito, M. and Gilles-Gonzalez, M. A. et al. (2002) Biochemistry 41, 4819-4826.

18) Chang, A. L., Tuckerman, J. R., Gilles-Gonzalez, M. A. et al. (2001) Biochemistry 40, 3420-3426.

19) Delgado-Nixon, V. M., Gonzalez, G. and Gilles-Gonzalez, M. A. (2000) Biochemistry 39, 2685-2691. 
青野重利( あおの しげとし)

岡崎国立共同研究機構統合バイオサイエンスセンター 教授, 工学博士

1987 年 3 月, 東京工業大学大学院理工学研究科博士課程修了後, 同年日本学術振興会特別研究員, 88 年ジョ ージア大学博士研究員, 89 年東京工業大学助手, 94 年北陸先端科学技術大学院大学助教授, 2002 年 5 月より 現職, 分子科学研究所教授兼任.

研究分野 : 遷移金属を含む金属タンパク質の生物無機化学的研究. 現在は, 金属含有センサータンパク質に 興味を持っている.

連絡先 : $=444-8585$ 愛知県岡崎市明大寺町字西鄉中 38

青野重利

E-mail: aono@ims.ac.jp 